\title{
De doeltreffendheid van een Italiaanse versus Nederlandse slagzin in een Italiaanse wijnreclame
}

Raedts Mariet

Dupré Natalie

\begin{abstract}
Foreign languages are commonly used in advertising, because it is generally thought that they attract consumers' attention. Compared to English, Italian is only rarely chosen by European advertisers. Precisely because of their low frequency, Italian words have a higher chance to capture and hold the consumers' attention.
\end{abstract}

Although foreign languages are widespread in advertising, the effectiveness of their use has not been studied extensively. In our study on print advertisements we compare the effectiveness of a foreign language slogan (Italian) relative to a slogan in the local language (Dutch). More specifically, we focus on the effects of foreign language usage on cognitive, affective and conative consumer responses. Cognitive responses include spontaneous and prompted recall of the slogan and the brand name. Affective responses pertain to the attitude towards the slogan, the brand and the advertisement. Conative response was defined in terms of purchase intention.

Our sample consisted of 236 subjects of different age and educational level from the Dutch speaking part of Belgium. These participants had little or no knowledge of the Italian language. 
The experiment had a between-subjects design. Participants either saw the Italian or the Dutch version of the advertisement. In order to optimize the effectiveness of the use of the foreign language, we ensured a match between foreign language, country of origin, and the advertised product. Therefore, we created an advertisement for Italian wines with visual elements (a picture and a drawing) evoking Italy. Additionally, we chose easy Italian words, as previous research has shown that slogans with easy foreign words are more appreciated than difficult slogans.

The results of our study show that the Dutch slogan was more effective for the spontaneous and prompted recall of the brand name. The language of the slogan had no effect on participants' attitudes towards the brand, the slogan and the advertisement. By contrast, the Italian slogan had a positive effect on participants' purchase intentions. The article ends with some concluding remarks and suggestions for future research. 


\section{Inleiding}

"Pizza zoals la mamma hem maakte". Deze zin kent u wellicht uit de reclamespot van Casa di Mama. Het is een van de weinige voorbeelden in het Nederlandse taalgebied van een reclameboodschap die Italiaans bevat. Omdat deze taal zo weinig voorkomt, is er een hogere kans dat advertenties of commercials met Italiaans niet onopgemerkt blijven. De veronderstelling dat vreemde talen een reclameboodschap doen opvallen en als gevolg daarvan de aandacht van de consument trekken, is een vaak genoemde reden voor het inzetten van vreemde talen in reclame (zie o.a. Ahn \& La Ferle, 2008; Domzal, Hunt, \& Kernan, 1995; Kelly-Holmes, 2005; Petrof, 1990; Piller, 2003).

Zodra een reclameboodschap de aandacht van de consument getrokken heeft en vasthoudt, kunnen de beoogde communicatiedoelstellingen bereikt worden (Hultink \& Schoormans, 2004). Die communicatiedoelstellingen worden doorgaans ingedeeld in drie categorieën: cognitieve (o.a. vergroten van merkbekendheid en productkennis), affectieve (o.a. beïnvloeden van de attitude en merkvoorkeur) en conatieve (o.a. vergroten van de koopintentie). Op basis van deze driedeling presenteren wij in de volgende paragraaf een overzicht van de publicaties over de doeltreffendheid van vreemde talen in reclame. Eerst gaan wij in op de vraag of vreemde talen bijdragen tot een hogere recall van het merk en de inhoud van de reclameboodschap. Daarna bespreken wij voorgaand onderzoek waarin werd nagegaan of vreemde talen in reclame bijdragen aan een positievere evaluatie van het merk en de reclameboodschap. Vervolgens staan wij stil bij de vraag of vreemde talen in reclameboodschappen de gedragsintenties beïnvloeden. Ons literatuuroverzicht eindigt met een bespreking van twee parameters die de effectiviteit van vreemde talen in reclame verhogen: de moeilijkheidsgraad van de woorden in de vreemde taal en de mate waarin de vreemde taal past bij het product. 


\section{Theoretisch kader}

Een eerste communicatiedoelstelling van reclame is het creëren of vergroten van de naambekendheid en de kennis over het product (Hultink \& Schoormans, 2004). Of die doelstelling bereikt is, kan nagegaan worden via een recall meting. In de literatuur zijn er twee theorieën terug te vinden over de verwerking en recall van reclameboodschappen met vreemde talen. Domzal et al. (1995) belichten het gebruik van vreemde talen in reclame vanuit de information processing theory. Deze theorie beschouwt een advertentie of commercial als een stukje informatie dat zintuiglijk en cognitief verwerkt dient te worden tot een mentale voorstelling. Domzal et al. (2001) stellen dat de verwerking van een reclameboodschap in een vreemde taal meer cognitieve inspanning vergt dan het verwerken van een reclameboodschap in de eigen taal. Hierdoor stijgt de kans dat ontvangers de informatie uit de reclameboodschap opslaan en deze gegevens nadien gemakkelijker uit hun geheugen ophalen of herkennen tussen nieuwe informatie.

Volgens Domzal et al. (1995) heeft het gebruik van vreemde talen in reclame een positief effect op de recall van de reclameboodschap. Luna en Peracchio (2001), daarentegen, stellen dat vreemde talen leiden tot een lagere recall. Zij verklaren de verwerking en recall van reclameboodschappen met vreemde talen vanuit het Revised Hierarchical Model (RHM). Dit model gaat uit van tweetalige ontvangers met een dominante taal en een tweede taal die ze minder goed maar op een hoog niveau beheersen. Volgens het RHM worden boodschappen in de tweede taal minder goed onthouden dan boodschappen in de dominante taal omdat de semantische verwerking minder vlot verloopt in de tweede taal. Luna en Peracchio (2001) toonden echter aan dat die asymmetrie uitgevlakt kan worden door de visuele elementen van de reclameboodschap. Afbeeldingen die de tekst ondersteunen, dragen bij aan de conceptuele 
verwerking van de tekst in de tweede taal waardoor die evengoed onthouden wordt als een tekst in de dominante taal. Het is echter nog niet empirisch onderzocht of de recall effecten van Luna en Peracchio (2001) ook gelden voor ontvangers die de vreemde taal minder goed beheersen.

Binnen het domein van de marketing wordt recall beschouwd als een belangrijke parameter om de effectiviteit van een reclameboodschap te toetsen (Beerli \& Santana, 1999; Pavlou \& Stewart, 2000). Toch hebben maar enkele studies naar de effecten van vreemde talen deze variabele in hun design opgenomen. Petrof (1990) toonde aan dat Amerikaanse studenten de merknaam en de inhoud van Franse advertenties beter onthielden dan de merknaam en de inhoud van Engelse advertenties. Ahn en La Ferle (2008) stelden vast dat Koreaanse studenten de fictieve en betekenisloze merknaam van een fototoestel beter onthielden en herkenden wanneer die naam in westers schrift werd afgedrukt. De inhoud van de body copyvier uitspraken waarin telkens een eigenschap van het product genoemd werd - werd echter minder goed onthouden en herkend wanneer die volledig in het Engels was opgesteld. Mogelijk vormden het hoge aantal woorden en de westerse lettertekens een te grote barrière om de inhoud van de Engelse body copy tijdens de beperkte aanbiedingstijd grondig te verwerken.

Een tweede communicatiedoelstelling van reclame is het beïnvloeden van de attitude. Verschillende studies onderzochten of de houding tegenover het merk, de reclameboodschap en/of het product bepaald wordt door de aanwezigheid van een vreemde taal. De resultaten zijn niet eenduidig. Leclerc, Schmitt en Dubé (1994) manipuleerden de uitspraak van zes fictieve merknamen. De deelnemers (Amerikaanse studenten) kregen ofwel de Franse uitspraak ofwel de Engelse uitspraak te horen. Vervolgens werd hen meegedeeld welk product 
bij de merknaam hoorde: een hedonistisch product (bijv. parfum), een functioneel product (bijv. benzine) of een hybride product met zowel hedonistische als functionele eigenschappen (bijv. shampoo). Hedonistische producten werden door de studenten positiever geëvalueerd wanneer de merknaam een Franse uitspraak meekreeg. De deelnemers verkozen ook Frans klinkende merknamen voor dit type producten. Voor de appreciatie van (merknamen van) functionele en hybride producten maakte het niet uit of de merknaam een Engelse dan wel een Franse uitspraak meekreeg. Uit een tweede experiment met geschreven merknamen concludeerden Leclerc et al. (1994) dat Amerikaanse studenten positiever tegen hedonistische producten aankijken wanneer die een Franse merknaam hebben. Thakor en Pacheco (1997) voerden een vervolgexperiment uit bij Engelstalige Canadese studenten. Deze onderzoekers voegden een tweede vreemde taal toe aan het experimentele design: het Italiaans. Uit hun studie bleek echter dat de taal van de merknaam (Engels, Frans, Italiaans) geen invloed had op de houding tegenover de merknaam.

In een andere reeks attitude-onderzoeken lag de nadruk op de reclameboodschap. De Amerikaanse studenten in het onderzoek van Petrof (1990) evalueerden Franse advertenties minder positief dan Engelse advertenties. De Franse deelnemers in de studie van Spielmann en Delvert (2014) evalueerden een advertentie voor een zonnebril met een Engelse body copy positiever dan de versie in het Frans. Planken, Van Meurs en Radlinska (2010), ten slotte, vonden geen systematische verschillen in de attitude tegenover de advertentie en de afgebeelde producten in hun steekproef van Poolse studentes.

Een derde communicatiedoelstelling van reclame is het beïnvloeden van het gedrag van de consument. Petrof (1990) en Planken et al. (2010) vergeleken de koopintentie van studenten nadat zij advertenties in een vreemde taal (respectievelijk Frans en Engels) of advertenties in 
hun moedertaal gezien hadden. Beide studies concludeerden dat vreemde talen geen effect hadden op de voornemens van de studenten om de producten in de advertenties te kopen.

In de hierboven vermelde studies werd steeds de effectiviteit van reclameboodschappen met een vreemde taal vergeleken met de effectiviteit van reclameboodschappen in de lokale taal. Hieronder wordt stilgestaan bij enkele studies die onderzochten aan welke voorwaarden vreemde talen in reclame moeten voldoen om effectief te kunnen zijn. Achtereenvolgens wordt ingegaan op het effect van de moeilijkheidsgraad van de woorden en de mate waarin de vreemde taal past bij het product.

Het gebruik van vreemde talen in reclame is niet zonder risico. Begripstoetsen in Gerritsen et al. $(2000,2010)$ wezen uit dat Engelse woorden en zinnen niet begrepen werden door een grote groep van de Nederlandse ontvangers. Marketeers lopen dus het gevaar dat de ontvanger de boodschap verkeerd interpreteert of niet begrijpt. Domzal et al. (1995) pleiten daarom om gemakkelijke woorden te gebruiken in reclame die bedoeld is voor een anderstalig publiek. Wanneer de woorden te moeilijk zijn, haakt de ontvanger mogelijk af waardoor de vreemde taal haar doel voorbijschiet. Deze richtlijn werd empirisch aangetoond in twee Nederlandse studies. Hornikx en Starren (2006) stelden vast dat Nederlanders gemakkelijke Franse slagzinnen in reclameadvertenties voor Franse automerken meer waarderen dan Franse slagzinnen met moeilijke woorden. Verder toonde de studie een samenhang aan tussen de moeilijkheidsgraad van de slagzin en de voorkeur voor een Franse of Nederlandse slagzin. Drie op de vier deelnemers gaven de voorkeur aan de Nederlandse variant als de Franse slagzin (te) moeilijk was. Bij de gemakkelijke Franse slagzinnen was er sprake van een lichte voorkeur voor de Franse variant. In een vervolgstudie met Engelse en Nederlandse slagzinnen kwamen Hornikx, Van Meurs en De Boer (2010) tot vergelijkbare resultaten. 
Volgens Kelly-Holmes (2000, 2005) worden vreemde talen in reclame niet zozeer ingezet voor hun letterlijke betekenis maar voor de associaties die ze oproepen. Consumenten associëren vreemde talen met typische kenmerken en typische producten van het land waar ze gesproken worden. De taalkeuze moet volgens Domzal et al. (1995) dan ook logisch zijn. Over het belang van een goede overeenstemming tussen het product en het land van herkomst (country-of-origin effect) is al heel wat onderzoek gedaan in het domein van de marketing (voor een overzicht, zie Verlegh en Steenkamp, 1999). Uit die studies blijkt dat reclame voor passende producten (bijvoorbeeld Frankrijk en wijn) hoger gewaardeerd wordt dan reclame voor niet-passende producten (bijvoorbeeld Frankrijk en bier). Over het belang van een goede overeenkomst tussen de vreemde taal en het product is veel minder bekend. Hornikx, Van Meurs en Hof (2013) toonden aan dat het gebruik van vreemde talen effectiever is voor passende dan voor niet-passende producten, maar ook dat de effecten niet voor alle talen gelijk zijn. Frans in een advertentie voor een passend product had, in vergelijking met een advertentie voor een niet-passend product, een positief effect op de gepercipieerde productkwaliteit, de attitude tegenover het product en de koopintentie. Voor Spaans waren er positieve effecten voor passendheid voor de attitude ten opzichte van het product en voor de koopintentie. Voor Duits was er enkel een positief effect voor de koopintentie.

\section{Onderzoeksdoel en -vragen}

In deze studie vergeleken wij de doeltreffendheid van een Nederlandse en een Italiaanse slagzin in een printadvertentie voor Italiaanse wijnen. Meer specifiek onderzochten wij of er een verschil is in recall, attitude en koopintentie na het zien van de Nederlandse respectievelijk Italiaanse versie van de reclameboodschap. Onze studie vormt om diverse 
redenen een belangrijke aanvulling op eerder onderzoek. Ten eerste zijn de effecten van vreemde talen in reclame nog niet vaak bestudeerd en spreken de resultaten van de verschillende studies elkaar soms tegen. Ten tweede is het effect van het Italiaans bij een anderstalig publiek nauwelijks onderzocht. Voor zover wij weten, is er enkel de studie van Thakor en Pacheco (1997) over Italiaanse, Franse en Engelse merknamen. Ten derde werden de effecten van vreemde talen in reclame tot nog toe voornamelijk onderzocht bij studenten (cf. Ahn \& La Ferle, 2008; Gerritsen et al., 2010; Hornikx et al., 2013; Leclerc et al., 1994; Petrof, 1990; Planken et al., 2010; Thakor \& Pacheco, 1997). Wij streefden naar een heterogenere steekproef. Tot slot combineerden wij in ons onderzoek de communicatieeffecten 'kennis', 'attitude' en 'gedrag'. Voorgaande studies waarin de effecten van een vreemde taal vergeleken werden met die van de lokale taal, bestudeerden ofwel het effect op de recall van de merknaam en de inhoud van de reclameboodschap (Ahn \& La Ferle, 2008) ofwel het effect op de houding van de deelnemers en/of hun koopintentie (Hornikx et al., 2010; Hornikx \& Starren, 2006; Planken et al., 2010; Spielmann \& Delvert, 2014). Enkel Petrof (1990) onderzocht de drie effecten, maar deze studie is inmiddels meer dan 20 jaar oud.

Ons experiment is opgebouwd rond zes onderzoeksvragen. Onze eerste onderzoeksvraag handelt over de recall van de slagzin. Slagzinnen worden in reclame gebruikt ter ondersteuning van het merk. Volgens Kohli, Leuthesser en Suri (2007, p. 415) spelen ze een sleutelrol bij het opbouwen van merkidentiteit: slagzinnen zorgen voor merkdifferentiatie, versterken het merkimago en helpen het merk in het geheugen van de consument te griffen. Voor zover wij weten, zijn er geen studies die de recall van slagzinnen in de vreemde taal onderzochten. Wel zijn er studies die de recall voor de informatie over productkenmerken onderzochten. Het experiment van Ahn en La Ferle (2008) toonde aan dat informatie in de body copy van de advertentie beter onthouden wordt als die in de lokale taal gepresenteerd wordt. Op basis van die studie zou de recall voor de Nederlandse slagzin in onze studie hoger 
moeten zijn dan de recall van de Italiaanse slagzin. Er is echter sprake van belangrijke verschillen in het aangeboden materiaal. In Ahn en La Ferle (2008) moesten de deelnemers een veel omvangrijkere tekst verwerken in een ander schrift dan in onze studie het geval is. Afgaande op de studie van Luna en Peracchio (2001) zou de recall van de Italiaanse en Nederlandse slagzin in onze studie echter niet verschillen. Deze onderzoekers concludeerden dat tweetaligen de inhoud van een reclameboodschap even goed onthouden wanneer tekst- en beeldelementen elkaar versterken. Dit laatste is ook het geval voor onze advertentie. Een belangrijk verschil met de studie van Luna en Peracchio (2001) is evenwel dat hun deelnemers tweetalig waren en onze deelnemers weinig of geen kennis hadden van de vreemde taal. Het is dus niet zeker of de bevindingen van Luna en Peracchio (2001) ook voor onze participanten gelden. De bijhorende onderzoeksvraag luidt als volgt:

RQ1: Verschilt de spontane en de geholpen herinnering van een Italiaanse en een Nederlandse slagzin?

De tweede vraag richt zich op de recall van de merknaam. Eerdere studies (Petrof, 1990; Ahn \& La Ferle, 2008) stelden vast dat een merknaam in de vreemde taal beter onthouden wordt dan een merknaam in de lokale taal. Details over de merknamen in Petrof (1990) ontbreken. Ahn en La Ferle (2008) kozen voor een merknaam zonder inhoudelijke betekenis die duidelijk afgezonderd werd van de body copy. Bovendien werd de merknaam weergegeven in een ander schrift. In onze studie is er sprake van een betekenisvolle merknaam die verwijst naar de historische figuur van Leonardo Da Vinci. In het bijzonder voor wijnen is de merknaam een bepalende factor in de aankoopbeslissing: wijnmerken die verwijzen naar personen scoren hoog op koopintentie in de studie van Forbes en Dean (2013) over de effectiviteit van verschillende soorten wijnmerken. Aangezien we in tegenstelling tot Leclerc et al. (1994) kozen voor een eigennaam, bleef de merknaam identiek in beide versies. Uit ons onderzoek 
moet blijken of de recall voor de merknaam hoger is bij een slagzin in een vreemde taal. Onze eerste onderzoekvraag luidt daarom als volgt:

RQ2: Verschilt de spontane en de geholpen herinnering van de merknaam voor een advertentie met een Italiaanse slagzin van die voor een advertentie met een Nederlandse slagzin?

Met vragen drie tot en met vijf bestudeerden wij mogelijke attitude-effecten ten aanzien van de slagzin, de advertentie en het merk. Voor zover wij weten is dit de eerste studie waarin nagegaan werd of een slagzin in de lokale taal anders gewaardeerd wordt dan een slagzin in de vreemde taal. Hornikx en Starren (2006) en Hornikx et al. (2010) vergeleken enkel de waardering voor gemakkelijke en moeilijke slagzinnen in de vreemde taal, maar stelden wel vast dat Nederlanders gemakkelijk te begrijpen Franse en Engelse slagzinnen verkiezen boven hun Nederlandse equivalenten. Daarom bedachten wij een korte Italiaanse slagzin met gemakkelijke woorden. Onze studie moet uitwijzen of de resultaten van Hornikx en Starren (2006) en Hornikx et al. (2010) ook gelden voor Italiaanse slagzinnen in Vlaanderen. De derde onderzoeksvraag luidt bijgevolg als volgt:

RQ3: Verschilt de waardering voor de Italiaanse en de Nederlandse slagzin?

De vierde onderzoeksvraag gaat na of de attitude tegenover de advertentie samenhangt met de taal in de reclameboodschap. Voor deze variabele konden wij op voorhand geen verwachting formuleren. De resultaten van eerdere studies zijn immers niet eenduidig: Planken et al. (2010) vonden geen effect van de vreemde taal, Petrof (1990) stelde een negatief effect vast en Spielmann en Delvert (2014) een positief effect. De onderzoeksvraag luidt als volgt:

RQ4: Verschilt de waardering voor de advertentie met de Italiaanse slagzin en de advertentie met de Nederlandse slagzin? 
Uit voorgaand onderzoek blijkt dat consumenten een positievere houding aannemen tegenover (de producten van) het merk (Leclerc et al., 1994; Hornikx et al., 2013) wanneer de taal en het merk of product bij elkaar passen. Luna en Peracchio (2001) vonden geen verschillen in de productbeoordeling door tweetalige ontvangers wanneer de verbale en visuele componenten van de reclameboodschap elkaar versterkten. Ook in onze studie vullen tekst- en beeldmateriaal elkaar aan, maar in tegenstelling tot de steekproef van Luna en Peracchio (2001) beheersen onze deelnemers de vreemde taal op een zeer laag niveau. Met onze studie willen wij nagaan of congruente visuele elementen het effect van de vreemde taal ook uitvlakken bij deelnemers met een laag taalbeheersingsniveau. Onze vijfde onderzoeksvraag luidt daarom als volgt:

RQ5: Verschilt de waardering voor het merk naargelang de advertentie een Italiaanse of een Nederlandse slagzin bevat?

De zesde onderzoeksvraag spitst zich toe op de koopintentie. In Hornikx et al. (2013) was de koopintentie hoger voor producten die pasten bij de taal in vergelijking met producten die niet pasten bij de taal. In deze studie werd het effect van drie vreemde talen op de koopintentie bestudeerd (het Duits, het Frans en het Spaans). Wij daarentegen gaan na of de koopintentie verschilt na het zien van een advertentie in de vreemde taal of de lokale taal. Voorgaande studies met een vergelijkbaar design lieten geen effect zien van de vreemde taal (Petrof, 1990; Planken et al., 2010). Toch is het niet mogelijk om vooraf een verwachting te formuleren met betrekking tot de koopintentie voor onze studie. Petrof (1990) geeft geen details over de producten die in het experiment gebruikt werden. In Planken et al. (2010) was er slechts in een van de zes gevallen sprake van een product met een duidelijke link tussen taal en land. De laatste onderzoeksvraag luidt als volgt: 
RQ6: Verschilt de koopintentie naargelang de advertentie een Italiaanse of een Nederlandse slagzin bevat?

\section{Methode}

Wij kozen een product met een duidelijke link met het land van oorsprong van de vreemde taal in de slagzin: wijn. In een pretest met een binnen-proefpersoonontwerp lieten wij 45 Vlamingen $(42.2 \%$ vrouwen) met een gemiddelde leeftijd van 49.44 jaar $(S D=15.80)$ de volgende zeven wijnlanden beoordelen: Australië, Chili, Duitsland, Frankrijk, Italië, Spanje en Zuid-Afrika. Daaruit kwam de volgende top 3 naar voor: (1) Frankrijk, (2) Italië en (3) Spanje. Italië werd met andere woorden beschouwd als een typisch wijnland.

\subsection{Materiaal}

Voor het experiment ontwikkelden wij twee versies van een printadvertentie: versie a met een Nederlandse slagzin en versie b met een Italiaanse slagzin (zie Figuur 1). Om de kans op begrip van de Italiaanse slagzin te verhogen (cf. resultaten van Hornikx \& Starren, 2006 en Hornikx et al., 2010) bevatte de zin twee substantieven die heel erg lijken op hun Franse equivalenten: 'arte' (Frans: 'art') en 'vino' (Frans: 'vin'). Omdat Frans in Vlaanderen een verplicht vak is in het basisonderwijs en in het voortgezet onderwijs, gingen wij ervan uit dat de meeste Nederlandstalige Belgen via hun kennis van het Frans de betekenis van de Italiaanse slagzin konden achterhalen.

In tegenstelling tot Ahn en La Ferle (2008), selecteerden wij een wijnmerk met een betekenisvolle merknaam: 'Da Vinci'. Volgens Lerman en Garbarino (2002) roepen betekenisvolle merknamen bestaande associaties op, waardoor ze nadien gemakkelijker uit het 
geheugen opgehaald kunnen worden. Zoals te zien is in Figuur 1 zit de merknaam vervat in de slagzin en vormen beide elementen een inhoudelijk geheel. Door in de slagzin het betekeniswoord 'kunst' op te nemen, hebben wij de associatie tussen 'Da Vinci' en 'kunst' willen versterken.
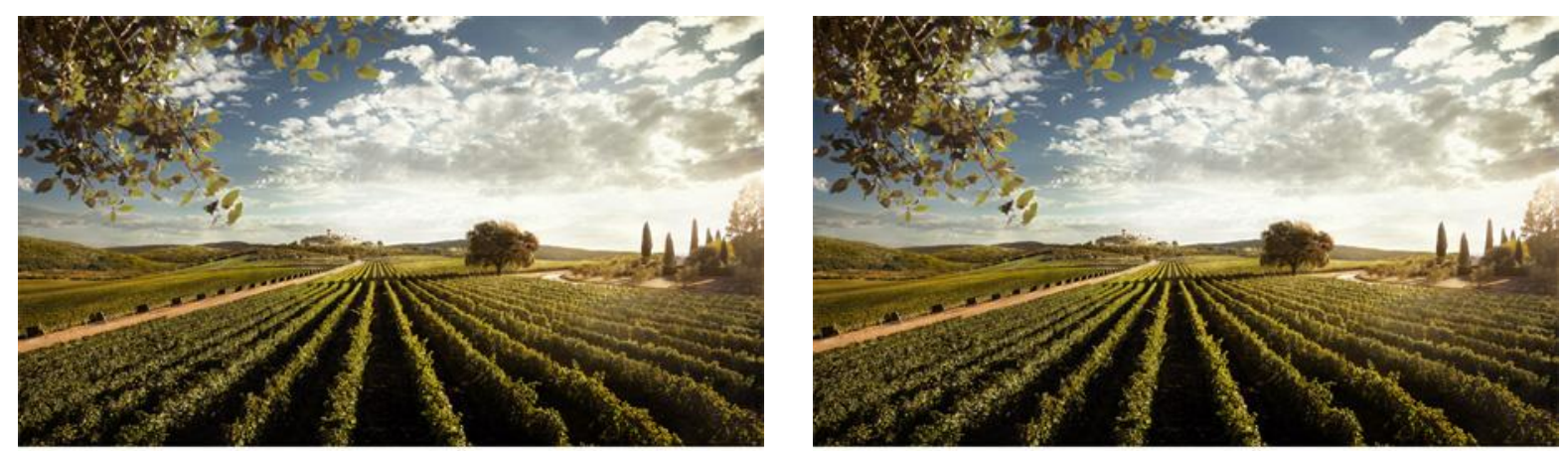

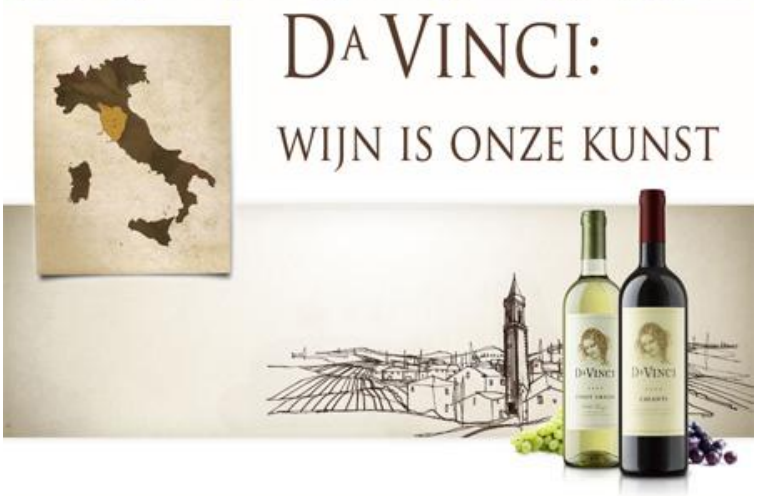

WWW.DAVINCIWINE.COM

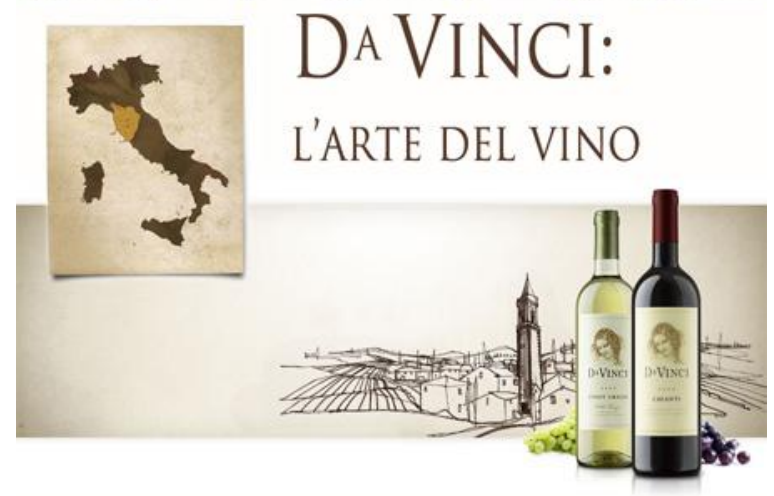

WWW.DAVINCIWINE.COM

Versie A: Nederlandse slagzin

Versie B: Italiaanse slagzin

Figuur 1. De twee versies van de advertentie.

Voor de lay-out baseerden wij ons op een bestaande advertentie voor Italiaanse wijn. Daarin werd bovenaan ook een typisch Italiaans landschap met een wijngaard afgebeeld. Met de resultaten van Luna en Peracchio (2001) in het achterhoofd, selecteerden wij afbeeldingen die een hoge mate van congruentie vertonen met de tekstelementen. De pentekening in de stijl 
van Leonardo Da Vinci zou associaties moeten oproepen met de merknaam 'Da Vinci' en het woord 'kunst/arte' in de slagzin. De afbeelding van het wijnlandschap bovenaan, de kaart van Italië en de wijnflessen sluiten aan bij het woord 'wijn/vino' uit de slagzin.

\subsection{Design en procedure}

Het onderzoek had een tussen-proefpersoonontwerp. Elke deelnemer kreeg één versie van de advertentie te zien. De versies werden at random toegewezen door Qualtrics, de web-based surveytool waarmee de data verzameld werden.

\subsection{Meetinstrument}

De vragenlijst bestond uit drie delen. In het eerste deel toonden wij een reeks van zes printadvertenties aan de deelnemers: drie met een alcoholische drank ( $2 x$ bier en $1 x$ wijn) en drie met een non-alcoholische drank ( $2 \mathrm{x}$ water en $1 \mathrm{x}$ melk). Elke afbeelding bleef acht seconden op het beeldscherm staan. Daarna schakelde Qualtrics automatisch over naar de volgende advertentie. De wijnadvertentie was de derde advertentie in de reeks. De andere vijf advertenties fungeerden als afleiders en waren volledig Nederlandstalig. Over deze advertenties werden geen vragen meer gesteld in de andere delen van de vragenlijst.

Daarna volgde een afleidingstaak (cf. Ahn \& La Ferle, 2008) die een vijftal minuten in beslag nam. Wij stelden vragen over het consumptie- en koopgedrag van alcoholische en nietalcoholische dranken en lieten de deelnemers watermerken verbinden met hun land van herkomst (bijv. San Pellegrino en Italië, Perrier en Frankrijk, Tönissteiner en Duitsland). De distractietaak eindigde met een advertentie van het Belgische watermerk Bru die de 
deelnemers moesten beoordelen. Hiervoor gebruikten wij dezelfde meetinstrumenten als voor de wijnadvertentie (cf. infra).

Het derde en laatste deel van de vragenlijst bevatte vragen over de recall van de merknaam en de slagzin van de wijnadvertentie, een begripsvraag over de slagzin, vragen over de houding van de deelnemers tegenover de advertentie, het merk en Italiaanse wijnen, hun productbetrokkenheid en hun koopintentie voor de afgebeelde producten. De meetinstrumenten worden hieronder in meer detail beschreven.

Recallmetingen van merk en slagzin. In navolging van onder andere Lerman en Garbarino (2002), Maughan, Gutnikov en Stevens (2007) en Ahn en La Ferle (2008) namen wij zowel een meting van spontane herinnering (spontaneous recall) als geholpen herinnering (prompted recall) op in onze vragenlijst. De spontane herinnering werd gemeten met een open vraag, en de geholpen herinnering via een meerkeuzevraag met vijf antwoordmogelijkheden voor de merknaam ('Da Vin Tee', 'Da Vini', 'Da Viti', 'Da Verdi', 'Da Vinci') en vijf antwoordmogelijkheden voor de slagzin ('Da Vinci: wijn \& kunst', 'Da Vinci: de kunst van het wijn maken', 'Da Vinci: wijn is onze kunst', 'Da Vinci: ons kunstwerk', 'Da Vinci: wijn wordt kunst'). De genoteerde merknamen werden gecodeerd als 'correct' of 'incorrect'. Met spelfouten hielden wij geen rekening. De door de participanten genoemde slagzinnen werden ingedeeld in twee categorieën: (1) incorrect (bijv. "wijn van de streek" of "le bon vin") of gedeeltelijk correct (bijv. "larte del vina" of "onze wijn is als kunst") of (2) volledig correct. Beide auteurs codeerden onafhankelijk van elkaar de antwoorden van de respondenten. De kappa bedroeg: .884. Na de recallmetingen werd de advertentie opnieuw afgebeeld.

Waardering voor de advertentie werd op twee manieren gemeten. Eerst vroegen wij de deelnemers hun spontaan waardeoordeel over de advertentie uit te drukken in de vorm van een cijfer van 1 tot 10 . Vervolgens legden wij vijf items (zevenpuntsschaal) voor aan de 
respondenten: "Ik vind de advertentie niet leuk/leuk, saai/boeiend, niet origineel/origineel, niet aantrekkelijk/aantrekkelijk en slecht/goed". De items werden overgenomen uit Hornikx en Hof (2008). De waardering voor de slagzin en de waardering voor het merk werden met dezelfde items gemeten. De betrouwbaarheid van de drie schalen was goed. Alle alfa-waardes waren groter dan .93 .

Koopintentie werd gemeten op basis van de volgende vier items: “Als ik kon kiezen, dan zou ik overwegen om de wijnen van Da Vinci te kopen", "Ik zou de wijnen van Da Vinci graag eens proberen", "Ik ben van plan om de wijnen van Da Vinci te kopen" en "Als ik de kans had, zou ik de wijnen van Da Vinci kopen”. Ook hier bestond de antwoordschaal uit zeven punten, met als uiterste schaalpunten 'helemaal niet eens' en 'helemaal eens'. Cronbach's alfa bedroeg 91 .

Bovenstaande constructen vormden de afhankelijke variabelen in onze studie. Daarnaast stelden wij vragen over het begrip van de slagzin (cf. Hornikx \& Starren, 2006; Hornikx et al., 2010), het country-of-origin image (cf. Sharma, 2011) en de productbetrokkenheid (cf. Ahn \& La Ferle, 2008). Deze drie constructen fungeerden in onze analyses als covariaten.

Begrip van de slagzin. Via de volgende open vraag gingen wij het begrip na van de slagzin: "Wat hebben de marketeers volgens u willen uitdrukken met de slagzin Da Vinci: wijn is onze kunst?". In de conditie met de Italiaanse slagzin werd de Italiaanse versie van de slagzin (Da Vinci: L'arte del vino) in de vraag opgenomen. Beide auteurs codeerden de antwoorden van de deelnemers onafhankelijk van elkaar $(\kappa=.756)$. Antwoorden werden gecodeerd als incorrect (bijv. "Dat de wijn lekker is"), als gedeeltelijk correct (bijv. "Dat het niet gewoon wijn is, maar een kunst. Dat het vakmanschap vergt om goede wijn te maken”) of als volledig correct (bijv. "Dat ze even sterk zijn in hun vak (wijn maken) als Leonardo Da Vinci in kunst"). 
De vragenlijst bevatte ook vragen over het country-of-origin image met betrekking tot wijn. Het meetinstrument namen wij over uit Sharma (2011). De items luidden als volgt: "Wijnen uit Italië zijn een goede aankoopkeuze", "Wijnen uit Italië zijn beter dan wijnen uit andere landen" en "Wijnen uit Italië zijn van hoge kwaliteit". Ook hier was de interne consistentie hoog: $\alpha=.84$.

Productbetrokkenheid werd gemeten met vier items. De eerste drie items werden overgenomen uit Jaeger, Danaher, en Brodie (2009): "Ik heb een sterke interesse in wijn", "Wijn is een belangrijk onderdeel van mijn levensstijl" en "Wijn drinken bezorgt me een plezierig gevoel”. Daarnaast gingen wij ook het wijnverbruik na van de deelnemers. De uiterste antwoordcategorieën waren: 'zelden of nooit' en 'zes tot zeven keer per week'. Een principale componenten analyse (CPA) wees uit dat de vier items samen een eendimensionale schaal vormen (factorladingen van .882 of hoger). De proportie verklaarde variantie bedroeg 82.5\%. Daarom werden de gemiddelde scores van de vier items gebruikt in de analyses. Cronbach's alfa voor de vier items bedroeg .93.

Aan het einde van de vragenlijst schatten de deelnemers hun kennis van het Italiaans (cf. Ahn \& La Ferle, 2008; Spielmann \& Delvert, 2014) en het Nederlands op een zevenpuntsschaal waarbij schaalpunt 1 stond voor 'zeer zwak' en schaalpunt 7 voor 'uitstekend'. De laatste vragen gingen over gender, leeftijd en opleidingsniveau.

\subsection{Deelnemers}

De vragenlijst werd ingevuld door 322 personen uit Vlaanderen tussen de 20 en 70 jaar oud. Uit deze steekproef verwijderden wij eerst alle deelnemers die geen moedertaalspreker van het Nederlands waren $(n=48)$. Dit waren personen die hun kennis van het Nederlands lager hadden ingeschaald dan schaalpunt 6 op de zevenpuntsschaal. Vervolgens sloten wij alle 
deelnemers uit die zichzelf op schaalpunt 4 of hoger hadden ingeschaald voor hun kennis van het Italiaans $(n=19)$. Hierdoor bestond onze steekproef enkel uit moedertaalsprekers van het Nederlands voor wie het Italiaans een onbekende taal was. Voor de vragen met betrekking tot de recall van de merknaam en de slagzin was het belangrijk dat de deelnemers voldoende aandacht aan de advertentie besteed hadden. Dankzij de timerfunctie in Qualtrics konden wij voor alle deelnemers afzonderlijk nagaan hoe lang zij naar de advertentie met de Italiaanse wijnen gekeken hadden. De door ons in Qualtrics ingestelde aanbiedingstijd was acht seconden. Deelnemers die minder dan drie seconden naar de wijnadvertentie gekeken hadden $(n=14)$, werden uit de steekproef verwijderd. Ook de deelnemers die de vragenlijst niet volledig hadden beantwoord, werden uit de data-analyses geweerd $(n=5)$.

Onze uiteindelijke steekproef bestond uit 236 personen. Hun gemiddelde leeftijd bedroeg 35.75 jaar $(S D=14.91)$. Vrouwen $(61.4 \%)$ en hoogopgeleiden (82.6\%) waren oververtegenwoordigd. De gemiddelde leeftijd van de deelnemers verschilde niet significant tussen de beide groepen $[t(234)=0.47, p=.638]$. Verder was er sprake van een gelijke verdeling van mannen en vrouwen $\left[\chi^{2}(1)=1.31, p=.253\right]$ en laag- en hoogopgeleiden $\left[\chi^{2}(1)\right.$ $=0.05, p=.459]$ over de beide condities.

\subsection{Statistische analyses}

Onderzoeksvragen 1 en 2 (effect van de vreemde taal voor de spontane en geholpen herinnering van de slagzin en de merknaam) toetsten wij met een logistische regressie. Om een antwoord te formuleren op onderzoeksvragen 3 tot en met 6 maakten wij gebruik van Ancova's. Telkens onderzochten wij het effect van de taal van de slagzin in een model waarin ook rekening werd gehouden met het begrip van de slagzin, het country-of-origin image en de mate van productbetrokkenheid. 


\section{Resultaten}

Voordat wij met de analyses startten, controleerden wij hoeveel personen de slagzin begrepen hadden. In de conditie met de Nederlandse slagzin kon $79.2 \%$ van de deelnemers een correcte omschrijving van de slagzin geven. In de conditie met de Italiaanse slagzin was dat $75 \%$. Dit verschil bleek niet significant: $\chi^{2}(1)=0.580, p=.446$. Onze opzet om een 'gemakkelijke' Italiaanse slagzin te creëren was dus geslaagd.

Daarna toetsten wij of de recall van de slagzin (RQ1) en de merknaam (RQ2) verschilde voor de advertentie met de Nederlandse en de advertentie met de Italiaanse slagzin. Tabel 1 presenteert hoeveel deelnemers zich de slagzin en de merknaam herinnerden na de distractietaak.

Tabel 1

Percentage deelnemers dat zich de slagzin en de merknaam herinnerde $(N=236)$

\begin{tabular}{llll}
\hline Recall van de slagzin & $\begin{array}{l}\text { Advertentie met } \\
\text { Nederlandse slagzin }\end{array}$ & $\begin{array}{l}\text { Advertentie met } \\
\text { Italiaanse slagzin }\end{array}$ & Totaal \\
\hline Spontane herinnering & $15.8 \%$ & $7.8 \%$ & $11.9 \%$ \\
Geholpen herinnering & $65.8 \%$ & $71.6 \%$ & $68.6 \%$ \\
\hline Recall van de merknaam & Advertentie met & Advertentie met & Totaal \\
& Nederlandse slagzin & Italiaanse slagzin & \\
\hline Spontane herinnering & $50.0 \%$ & $32.8 \%$ & $41.5 \%$ \\
Geholpen herinnering & $78.3 \%$ & $56.0 \%$ & $67.4 \%$ \\
\hline
\end{tabular}


Slechts een zeer kleine minderheid van de deelnemers kon zich de slagzin terug voor de geest halen na de distractietaak (zie Tabel 1). Een logistische regressieanalyse wees uit dat het model voor de spontane herinnering van de slagzin met de variabelen versie, country-oforigine image, productbetrokkenheid en begrip van de slagzin niet beter paste bij de data dan een model zonder deze variabelen: $\chi^{2}=10.164, d f=5, p=.07$.

Vervolgens werd een logistische regressie uitgevoerd om na te gaan welke variabelen de kans op geholpen herinnering van de slagzin voorspellen (RQ1). Een model met versie advertentie, begrip slagzin, country-of-origin image en productbetrokkenheid als voorspellende variabelen bleek significant: $\chi^{2}=21.383, d f=5, p<.01$. De uitkomsten van de analyse zijn weergegeven in Tabel 2. Via de Wald-statistics kan nagegaan worden welke variabelen een significante invloed hadden op de kans dat de slagzin onthouden werd. In de kolom exp(B) worden de odds ratio's weergegeven. Waarden groter dan 1 wijzen op een positief effect, bij een negatief effect ligt de waarde tussen 0 en 1 . In de laatste kolom staan de bijhorende betrouwbaarheidsintervallen. Wanneer de waarde 1 niet in het betrouwbaarheidsinterval zit, kan met $95 \%$ zekerheid gesteld worden dat de onafhankelijke variabele van invloed is op de afhankelijke variabele. De gegevens in Tabel 2 tonen dat enkel het begrip van de slagzin een goede voorspeller is voor de geholpen herinnering van de slagzin. Deelnemers die de slagzin gedeeltelijk of volledig begrepen hadden, hadden een hogere kans om de slagzin te herkennen na de distractietaak.

Tabel 2

Uitkomsten van de logistische regressie met als afhankelijke variabele 'geholpen herinnering slagzin' $(N=$ 236)

$\operatorname{Exp}(\mathrm{B}) \quad$ Wald $\quad 95 \% \mathrm{BI}$




\begin{tabular}{llrl}
\hline Versie advertentie (ref: Italiaanse versie) & 0.636 & 2.277 & $0.35-1.15$ \\
Begrip slagzin (ref: slagzin niet begrepen) & & 17.713 & \\
$\quad$ Slagzin gedeeltelijk begrepen & $2.711^{* *}$ & 8.304 & $1.38-5.34$ \\
$\quad$ Slagzin volledig begrepen & $6.179^{* *}$ & 16.948 & $2.60-14.70$ \\
Country-of-origin image & 0.854 & 1.598 & $0.67-1.09$ \\
Productbetrokkenheid & 1.125 & 1.793 & $0.95-1.34$ \\
\hline Nagelkerke pseudo $\mathrm{R}^{2}$ & 0.12 & & \\
\hline BI: betrouwbaarheidsinterval *p<.05**p<.01 & & & \\
\end{tabular}

Vervolgens werd een logistische regressie uitgevoerd om na te gaan welke variabelen de kans op spontane herinnering van de merknaam voorspellen (RQ2). Een model met versie advertentie, begrip slagzin, country-of-origin image en productbetrokkenheid als voorspellende variabelen bleek significant: $\chi^{2}=21.629, d f=5, p<.01$. De gegevens in Tabel 3 tonen dat twee variabelen de kans op spontane recall van de merknaam voorspellen: tekstversie en begrip slagzin. De kans op recall was significant groter voor de deelnemers die de versie met de Nederlandse slagzin zagen en voor de deelnemers die de slagzin volledig begrepen hadden. Begrip was een relatief betere voorspeller dan tekstversie in het model.

Tabel 3

Uitkomsten van de logistische regressie met als afhankelijke variabele 'spontane herinnering merknaam' $(N=236)$

\begin{tabular}{lccc}
\hline & $\mathbf{E x p ( B )}$ & Wald & $\mathbf{9 5 \%} \mathbf{B I}$ \\
\hline Versie advertentie (ref: Italiaanse versie) & $1.995^{*}$ & 6.111 & $1.15-3.45$ \\
Begrip slagzin (ref: slagzin niet begrepen) & & 11.224 &
\end{tabular}




$\begin{array}{llll}\text { Slagzin gedeeltelijk begrepen } & 1.163 & 0.177 & 0.58-2.35 \\ \text { Slagzin volledig begrepen } & 3.103^{* *} & 8.105 & 1.42-6.77 \\ \text { Country-of-origin image } & 1.226 & 2.885 & 0.97-1.55 \\ \text { Productbetrokkenheid } & 0.999 & 0.000 & 0.85-1.17\end{array}$

Nagelkerke pseudo $\mathrm{R}^{2}$

0.12

BI: betrouwbaarheidsinterval $* p<.05 * * p<.01$

In Tabel 4 worden de resultaten van de logistische regressie voor de geholpen herinnering van de merknaam weergegeven (RQ2). Ook dit model paste significant beter bij de data dan het model zonder de onafhankelijke variabelen: $\chi^{2}=24.287, d f=5, p<.001$. Net zoals bij de spontane herinnering beïnvloedden enkel de tekstversie en het begrip van de slagzin de kans op geholpen herinnering van de merknaam. De participanten die de Nederlandstalige advertentie gezien hadden, hadden een hogere kans om de merknaam te herkennen. Ook de deelnemers die de slagzin volledig begrepen hadden, hadden een grotere kans om de merknaam te herkennen tussen de afleiders.

Tabel 4

Uitkomsten van de logistische regressie met als afhankelijke variabele 'geholpen herinnering merknaam' $(N=236)$

\begin{tabular}{lccc}
\hline & $\mathbf{E x p}(\mathbf{B})$ & Wald & $\mathbf{9 5 \%} \mathbf{B I}$ \\
\hline Versie advertentie (ref: Italiaanse versie) & $2.771^{* *}$ & 11.606 & $1.54-4.98$ \\
Begrip slagzin (ref: slagzin niet begrepen) & & 8.524 & \\
$\quad$ Slagzin gedeeltelijk begrepen & 0.857 & 0.191 & $0.43-1.71$ \\
$\quad$ Slagzin volledig begrepen & $2.665^{*}$ & 4.795 & $1.11-6.41$ \\
Country-of-origin image & 1.145 & 1.157 & $0.90-1.46$
\end{tabular}


Nagelkerke pseudo $\mathrm{R}^{2}$

0.14

BI: betrouwbaarheidsinterval $* p<.05 * * p<.01$

Via Ancova's toetsten wij vervolgens het effect van de taal van de slagzin op de waardering voor de slagzin (RQ3), de waardering voor de advertentie (RQ4), de waardering voor het merk (RQ5) en de koopintentie RQ6). De versie van de advertentie fungeerde in elke analyse als de factor, begrip van de slagzin, country-of-origin image en productbetrokkenheid werden meegenomen als covariaten. Op die manier controleerden wij telkens voor het effect van de net genoemde drie variabelen. In Tabel 5 zijn de gemiddelde scores en standaarddeviaties weergegeven voor de zes afhankelijke variabelen in de beide condities.

Tabel 5

Gemiddelde scores en standaarddeviaties voor de afhankelijke variabelen opgesplitst naar slagzin

\begin{tabular}{|c|c|c|c|c|c|c|}
\hline \multirow{2}{*}{$\begin{array}{l}\text { Variabele } \\
\text { Waardering voor de slagzin }\end{array}$} & \multicolumn{2}{|c|}{$\begin{array}{l}\text { Nederlandse slagzin } \\
\mathbf{N}=\mathbf{1 2 0}\end{array}$} & \multicolumn{2}{|c|}{$\begin{array}{l}\text { Italiaanse slagzin } \\
\mathrm{N}=116\end{array}$} & \multicolumn{2}{|c|}{$\begin{array}{l}\text { Totaal } \\
\text { N = 236 }\end{array}$} \\
\hline & 4.60 & $(1.33)$ & 4.77 & $(1.34)$ & 4.68 & $(1.34)$ \\
\hline Rapportcijfer $^{1}$ advertentie & 6.99 & $(1.34)$ & 7.13 & $(1.45)$ & 7.06 & $(1.41)$ \\
\hline Waardering advertentie & 4.72 & $(1.94)$ & 4.70 & $(1.33)$ & 4.71 & $(1.26)$ \\
\hline Waardering merk & 4.28 & $(1.16)$ & 4.46 & $(1.17)$ & 4.37 & $(1.65)$ \\
\hline Koopintentie & 3.44 & $(1.58)$ & 4.02 & $(1.41)$ & 3.73 & $(1.52)$ \\
\hline
\end{tabular}


De resultaten van de Ancova's zijn samengevat in Tabel 6. Daarin is te zien dat de taal van de slagzin enkel een effect had op de koopintentie. Deelnemers die de advertentie met de Italiaanse slagzin kregen, hadden een hogere koopintentie dan de deelnemers aan wie wij de advertentie met de Nederlandse slagzin toonden. Wat de covariaten betreft, bleek begrip van de slagzin een significante impact te hebben op de waardering voor de slagzin, de waardering voor het merk en de koopintentie. Een positief oordeel over Italiaanse wijnen had ook een positief effect op het globale kwaliteitsoordeel voor de advertentie, de waardering voor de advertentie, de waardering voor het merk en de koopintentie. Productbetrokkenheid, ten slotte, beïnvloedde positief de waardering voor de slagzin en voor het merk en de koopintentie. 
Tabel 6

Resultaten van de afzonderlijke Ancova's voor de afhankelijke variabelen (significante p-waardes zijn onderlijnd)

\begin{tabular}{|c|c|c|c|c|c|c|c|c|c|c|c|c|}
\hline & \multicolumn{3}{|c|}{ Taal slagzin } & \multicolumn{3}{|c|}{ Begrip slagzin } & \multicolumn{3}{|c|}{ COO-image } & \multicolumn{3}{|c|}{ Productbetrokkenheid } \\
\hline & $\mathrm{F}$ & $\mathrm{p}$ & $\eta_{\mathrm{p}}^{2}$ & $\mathrm{~F}$ & $\mathrm{p}$ & $\eta_{\mathrm{p}}^{2}$ & $\mathrm{~F}$ & $\mathrm{p}$ & $\eta_{\mathrm{p}}^{2}$ & $\mathrm{~F}$ & $\mathrm{p}$ & $\eta_{\mathrm{p}}^{2}$ \\
\hline Waardering voor de slagzin & 1.424 & .234 & - & 12.081 & .001 & .05 & 3.823 & .052 & - & 6.599 & .011 & .03 \\
\hline Rapportcijfer advertentie & 0.516 & .473 & - & 2.437 & .120 & - & 5.258 & .023 & .02 & 2.895 & .090 & - \\
\hline Waardering advertentie & 0.028 & .867 & - & 2.810 & .095 & - & 7.137 & .008 & .03 & 3.104 & .079 & - \\
\hline Waardering merk & 1.559 & .213 & - & 8.851 & .003 & .04 & 15.545 & .000 & .06 & 5.488 & .020 & .02 \\
\hline Koopintentie & 11.318 & .001 & .05 & 5.217 & .023 & .02 & 45.134 & .000 & .16 & 44.767 & .000 & .16 \\
\hline
\end{tabular}




\section{Conclusie en discussie}

In deze studie vergeleken wij de doeltreffendheid van een Nederlandse en Italiaanse slagzin in een printadvertentie voor Italiaanse wijnen aan de hand van recall, attitude en koopintentie. Wat de recall van de slagzin betreft, constateerden wij geen verschillen tussen de Italiaanse en de Nederlandse versie. Deze resultaten zijn mogelijk toe te schrijven aan de hoge congruentie tussen tekst- en beeldelementen in onze advertentie (cf. Luna \& Peracchio, 2001). Overigens moet hier vermeld worden dat de spontane herinnering van de slagzin zeer laag was. Minder dan één op de zes deelnemers kon zich de Nederlandse slagzin spontaan herinneren. Voor de Italiaanse slagzin was dat zelfs minder dan één op de tien. Mogelijk kan het eenmalige contact met de slagzin en de korte aanbiedingstijd (maximum acht seconden) een verklaring bieden voor de lage recall van zowel de Italiaanse als de Nederlandse slagzin.

Onze studie wees verder uit dat de spontane en geholpen herinnering van de merknaam hoger was voor de Nederlandse versie van de advertentie dan voor de Italiaanse versie van de slagzin. De lagere recall van de merknaam in de Italiaanse versie is mogelijk het gevolg van de anderstalige slagzin. Tijdens de korte aanbiedingstijd hebben de deelnemers wellicht vooral gefocust op de woorden van de Italiaanse slagzin.

Voor de attitudemetingen vonden we geen significante verschillen. De verklaring hiervoor ligt volgens ons in de lay-out van onze advertentie. De visuele component was veel prominenter aanwezig dan de tekstuele. Bij het evalueren van het merk, de slagzin en de advertentie hebben de deelnemers zich mogelijk veel meer laten leiden door de afbeeldingen en foto's dan door de tekstelementen.

Waar verschillen op attitudemetingen tussen de Nederlandse en Italiaanse slagzin ontbraken, was de koopintentie wel hoger bij de Italiaanse slagzin. Dat het Italiaans hoger scoort is 
wellicht niet vreemd: in de conditie met de Italiaanse slagzin pasten de taal, het product en het land perfect bij elkaar (cf. Hornikx et al., 2013).

Zoals elke studie heeft ook ons onderzoek zijn sterke en zwakke punten. Een eerste beperking betreft de steekproef die alleen uit proefpersonen uit Vlaanderen en hoofdzakelijk uit hoogopgeleiden bestond. Ten tweede gelden de resultaten van onze studie maar voor één vreemde taal en één product. Replicatiestudies moeten uitwijzen of onze bevindingen gegeneraliseerd kunnen worden naar andere landen, talen en producten. Een derde beperking betrof de keuze van de merknaam. Die verwees naar een historische figuur. Ontvangers die de figuur niet kenden, konden geen semantische verbinding maken met de slagzin, waardoor ook de verwijzing naar 'kunst' en de pentekening in de advertentie verloren ging. Een laatste beperking van dit onderzoek was de korte aanbiedingstijd van de advertentie. Doordat de respondenten de advertentie maar één keer kort te zien kregen, beschikten zij mogelijk over te weinig tijd om deze grondig te bekijken en te verwerken. In vervolgonderzoek zou kunnen nagegaan worden wat het effect is van een lange versus korte aanbiedingstijd.

In vervolgonderzoek kan ook worden gekeken naar de mogelijke invloed van de betrokkenheid van de respondenten bij het land en naar de mogelijke invloed van hun houding tegenover de vreemde taal in de advertentie. Respondenten die een band hebben met het land kijken wellicht anders naar de advertentie dan respondenten die het land nog nooit bezocht hebben of er geen interesse voor tonen. Ook de houding tegenover de taal zou de recall, attitude en koopintentie in positieve of negatieve zin kunnen beïnvloeden.

Een andere piste voor verder onderzoek ligt in het manipuleren van de visuele elementen van de reclameboodschap. In onze advertentie namen de afbeeldingen en foto's een prominente plaats in. In een vervolgstudie zou een vergelijking gemaakt kunnen worden tussen een visueel rijke en een eerder sobere advertentie. In een advertentie met weinig beeldmateriaal 
vallen de tekstelementen beter op en worden er mogelijk andere effecten gevonden voor het gebruik van de vreemde taal. Verder zou het effect van visuele elementen die verwijzen naar het land van oorsprong vergeleken kunnen worden met beeldmateriaal zonder verwijzingen naar het land van herkomst (cf. Hornikx et al., 2013).

Ten slotte zou vervolgonderzoek met een eyetracker inzicht kunnen bieden in de manier waarop gekeken wordt naar reclame met anderstalige woorden. Op die manier zou de veronderstelling dat woorden in de vreemde taal de aandacht trekken en vasthouden (Domzal et al., 1995), empirisch bewezen of ontkracht kunnen worden. Bovendien zou nagegaan kunnen worden hoeveel aandacht ontvangers besteden aan de visuele en tekstuele onderdelen van de advertentie.

Met onze studie hebben we een bijdrage willen leveren aan het onderzoek over vreemde talen in reclame. Wij hopen dat we met onze voorstellen voor verder onderzoek anderen kunnen inspireren om vernieuwende experimenten op te zetten over het gebruik van vreemde talen in reclame. 


\section{Referenties}

Ahn, J., \& La Ferle, C. (2008). Enhancing recall and recognition for brand names and body copy: A mixed-language approach. Journal of Advertising, 37(3), 107-117.

Beerli, A., Santana, J. D. M. (1999). Design and validation of an instrument for measuring advertising effectiveness in the printed media. Journal of Current Issues and Research in Advertising, 21(2), 11-30.

Domzal, T.J., Hunt, J.M., \& Kernan, J.B. (1995). Achtung! The information processing of foreign words in advertising. International Journal of Advertising, 14(2), 95-114.

Forbes, S.L., \& Dean, D. (2013). Consumer perceptions of wine brand names. Geraadpleegd via http://researcharchive.lincoln.ac.nz/handle/10182/5657

Gerritsen, M., Korzilius, H., Meurs, F. van, \& Gijsbers, I. (2000). English in Dutch commercials: Not understood and not appreciated. Journal of Advertising Research, 40(4), $17-31$.

Gerritsen, M., Nickerson, C., Hooft, A. van, Meurs, F. van, Korzilius, H., Nederstigt, U., Starren, M., \& Crijns, R. (2010). English in product advertisements in non-English-speaking countries in Western Europe: Product image and comprehension of the text. Journal of Global Marketing, 23(4), 349-365.

Hornikx, J., \& Hof., R. (2008). De effectiviteit van vreemde talen in productreclame: moet het product passen bij de taal? [The effectiveness of foreign languages in advertising: Does the product have to match with the language?] Tijdschrift voor Taalbeheersing, 30(2), 147-156.

Hornikx, J., \& Starren, M. (2006). The relationship between the appreciation and the comprehension of French in Dutch advertisements. In R. Crijns \& C. Burgers (Eds.), Werbestrategien in Theorie und Praxis: Sprachliche Aspekte von deutschen und 
niederländischen Unternehmensdarstellungen und Werbekampagnen (pp. 129-145). Tostedt: Attikon Verlag.

Hornikx, J., Meurs, F. van, \& Boer, A. de (2010). English or a local language in advertising? The appreciation of easy and difficult English slogans in the Netherlands. Journal of Business Communication, 47(2), 169-188.

Hornikx, J., Meurs, F. van, \& Hof, R.-J. (2013). The effectiveness of foreign-language display in advertising for congruent versus incongruent products. Journal of International Consumer Marketing, 25(3), 152-165.

Hultink, E.J., \& Schoormans, J. (2004). Productontwikkeling en marketing. Amsterdam: Pearson Benelux.

Jaeger, S.R., Danaher, P.J., \& Brodie, R.J. (2009). Wine purchase decisions and consumption behaviours: Insights from a probability sample drawn in Auckland, New Zealand. Food Quality and Preference, 20, 312-319.

Kelly-Holmes, H. (2000). Bier, parfum, kaas: Language fetish in European advertising. European Journal of Cultural Studies, 3(1), 67-82.

Kelly-Holmes, H. (2005). Advertising as multilingual communication. Basingstoke: Palgrave Macmillan.

Kohli, C., Leuthesser, L., \& Suri, R. (2007). Got slogan? Guidelines for creating effective slogans. Business Horizons, 50(5), 415-422.

Leclerc, F., Schmitt, B.H., \& Dubé, L. (1994). Foreign branding and its effects on product perceptions and attitudes. Journal of Marketing Research, 31(2), 263-270. 
Lerman, D., \& Garbarino, E. (2002). Recall and recognition of brand names: A comparison of word and nonword name types. Psychology \& Marketing, 19(7-8), 621-639.

Luna, D., \& Peracchio, L. (2001). Moderators of language effects in advertising to bilinguals: A psycholinguistic approach. Journal of Consumer Research, 28(2), 284-295.

Maughan, L., Gutnikov, S., \& Stevens, R. (2007). Like more, look more. Look more, like more: The evidence from eye-tracking. Brand Management, 14(4), 335-342.

Pavlou, P.A., \& Stewart, D.W. (2000). Measuring the effects and effectiveness of interactive advertising. Journal of Interactive Advertising, 1(1), 61-77.

Petrof, J.V. (1990). L'utilisation des langues étrangères comme moyen d'augmenter l'efficacité de la publicité: Une approche expérimentale. Recherche et Applications en Marketing, 5(2), $1-16$.

Piller, I. (2003). Advertising as a site of language contact. Annual Review of Applied Linguistics, 23, 170-183.

Planken, B., Meurs, F. van, \& Radlinska, A. (2010). The effects of the use of English in Polish product advertisements: Implications for English for business purposes. English for Specific Purposes, 29(4), 225-242.

Sharma, P. (2011). Demystifying cultural differences in country-of-origin effects: Exploring the moderating roles of product type, consumption context, and involvement. Journal of International Consumer Marketing, 23(5), 344-364.

Spielmann, N., \& Delvert, M. (2014). Adapted or standardized copy: Is non-cultural English the answer? Journal of Business Research, 67, 434-440. 
Thakor, M.V., \& Pacheco, B.G. (1997). Foreign branding and its effects on product perceptions and attitudes: A replication and extension in a multicultural setting. Journal of Marketing Theory and Practice, 5(1), 15-30.

Verlegh, P.W.J., \& Steenkamp, J.-B. E.M. (1999). A review and meta-analysis of country-oforigin research. Journal of Economic Psychology, 20, 521-546. 